\title{
LANGUAGE AS A TOOL FOR COMMUNICATION AND CULTURAL REALITY DISCLOSER ${ }^{1}$
}

\author{
Sitti Rabiah $^{2}$ \\ Faculty of Letter \\ Universitas Muslim Indonesia, Makassar
}

\begin{abstract}
Language is a communication tool used by everyone in their daily life as a means to convey information and arguments to others. In this case, the language cannot be separated from culture because language represent its nation and has close relation to the attitude or behavior of groups of speakers of the languages. The role of language as a tool to express culture reality can be seen from: 1) Language is part of culture, 2) Even the language and the culture is in different, but have a very close relationship, 3) Language is strongly influenced by culture, and 4) Language significantly influence culture and way of thinking of people living within. In the communication, language used by people is influence their culture or vice versa. If used parables, the culture and language like Siamese twins, the two things that cannot be separated. Or as a coin; side one is the language and the other is culture.
\end{abstract}

Keywords: Language, Communication, Cultural reality

\begin{abstract}
Abstrak
Bahasa merupakan alat komunikasi yang digunakan oleh setiap orang dalam kesehariannya sebagai sarana untuk menyampaikan informasi maupun argumen kepada orang lain. Dalam hal ini, Bahasa juga tidak terlepas dengan Budaya, dikarenakan Bahasa menunjukkan bangsa dan sangat erat kaitannya dengan sikap atau perilaku kelompok masyarakat penutur bahasa tersebut. Peran Bahasa sebagai pengungkap realitas Budaya ditunjukkan dari: 1) Bahasa merupakan bagian dari kebudayaan, 2) Bahasa dan kebudayaan merupakan hal yang berbeda, namun mempunyai hubungan yang sangat erat, 3) Bahasa sangat dipengaruhi oleh kebudayaan, dan 4) Bahasa sangat mempengaruhi kebudayaan dan cara berpikir. Dalam berkomunikasi inilah, Bahasa yang digunakan seseorang dipengaruhi atau mempengaruhi budaya pengguna bahasa tersebut. Jika digunakan perumpamaan, Bahasa dengan kebudayaan bagaikan bayi kembar siam, yakni dua hal yang tidak bisa dipisahkan. Atau sebagai sekeping mata uang; sisi yang satu adalah bahasa dan sisi yang lain adalah kebudayaan.
\end{abstract}

Kata Kunci: Bahasa, Komunikasi, Realitas Budaya

\section{A. Introduction}

Language indicates each of its nation, a parable once say so. If its meaning pondered deeper, may make us wiser in understanding and addressing all cases that linked between language and attitude or behavior of groups of speakers of the languages. (Alwi, 2004:21). Wisdom is likely to strengthen believe about the role of language in the development of the culture.

\footnotetext{
1 Presented in $1^{\text {st }}$ International Conference on Media, Communication and Culture "Rethinking Multiculturalism: Media in Multicultural Society" organized by Universitas Muhammadiyah Yogyakarta and Universiti Sains Malaysia on November, 7th - 8th 2012 in Universitas Muhammadiyah Yogyakarta, Indonesia.

2 (Di) https:// orcid.org/ 0000-0002-1690-0025. Corresponding author: sitti.rabiah@umi.ac.id / sittirabiah25@gmail.com
} 
There are several theories on the relationship of language and culture. Some say that even language is part of culture but they are different, but in terms of relation they are very close each other, so it cannot be separated. Some say that the language is strongly influenced by culture, so that all things in the culture will be reflected in the language. Conversely, there is also a saying that language influence culture, and the human or their speakers way of thinking. This paper intended to discuss the nature of language, the nature of culture and how language can express the cultural reality of the language users.

\section{B. The Nature of Language}

Various definition of the language has been proposed by linguists. Language is a form, not the substance (in Chaer Lyons 1995:60). While Chaer (1995:14) mentions the characteristics that constitute the essence of language as a symbol of the sound system, are arbitrary, productive, dynamic, diverse, and humane.

Language as a system, which means that formed by a number of components that are fixed and can be patterned. As a system, in addition to the systematic language are also systemic. Systematic meaning, language arranged according to a certain pattern, not arranged randomly or arbitrarily. While systematic means that language is a single system, but rather consists of several subsystems that differ from other languages. Language subsystem consists of phonology, morphology, syntax, and lexicon. Therefore the language also commonly considered unique but universal at the same time. Unique means having the characteristics or properties not possessed by other languages, while universal means having the same traits that exist in all languages.

When compared with animals that have a variety of forms of communication, so people just use the language. Basically there are two types of animal communication systems: first, communication systems found in the bees. The second all communication systems exist in monkeys and birds. Human languages have something similar to this communication, but has a major difference compared to both (Gee, 1993: 2). Bees can communicate the presence of nectars to their group members, like the distance of the nectars, direction to the location, and the number of nectar found by using a particular dance. Gee called the bee dance to communicate the presence of the nectar as point-bypoint system. In addition to bees, monkeys and birds also have a way to communicate. Vervet African apes are capable to produce 36 kinds of sound for various situations. Among them was a different sound for the same situation, so vervet communication system able to deliver 22 kinds of messages. In addition, the birds also have a way to communicate even only consist of a very limited vocabulary to deliver messages.

Furthermore, Chaer and Agustina (2004:26-29) suggests 16 kinds of distinctive human language, as follows:

1) The language uses vowel auditory pathway. In this case, there are similarities between communication systems owned by many animals, including crickets, frogs, and birds. 
2) Language can be spread in all directions; yet receptions are directed. Spoken language sounds can be heard in all directions due to noise or sounds of language that propagates through the air, but the receiver or listener can tell exactly from which direction the sounds of language came.

3) The language symbol in the form of sound that can be disappear once pronounced. This is in contrast with another symbol, such as the footprints of animals and heroic statues that can last for long time. Because of the rapid loss, people always trying to preserve this symbol of language sounds into written form and sound recordings.

4) Participants in the communication with language can communicate to each other. This means that a speaker can be a symbol sender and as symbol recipient at the same time.

5) The language symbol can be a complete feedback. The speaker as the sender can hear their own language symbols. Whereas, in some kinetic communication (movement) and visual (sight) as the bee dance, the sender information is not able to see the important parts of the dance.

6) Communication languages has its own specialty. Humans can talk without having to do physical movements to support the communication process. Whereas communication in bees they physically forced to dance in order to deliver messages they intended to.

7) Sound symbols in communication language means and refers to certain things. For example the word of horse refers to a type of quadrupeds that can be ridden. Sentence "Chaedar kick the ball" mean someone named Chaedar doing actions that hit the ball with his leg.

8) The relationship between language symbol with its meaning is not determined by the presence of a bond between the two, but is determined by agreement or convention between the speakers of the language.

9) language as a tool of human communication can be separated into certain unit, i.e sentences, words, morphemes, and phonemes.

10) Reference or something being discussed in the language not always be at the present place and time. Human language can be used for something in the past, in the future, or are in distant places. Even that only in fantasy.

11) Language is open. It means, symbols of speech can be made according to the human needs. While the language of animals is closed, unchanged from the first.

12) Skill and finesse to master the rules and customs of human language derived from learning process, not through genes inborn. Animal language generally be congenital. 
13) The language can be learned. Someone who was born and raised in a particular language community will be able to learn other languages that not used in their community.

14) Language can be used to express the true and not true, or logically meaningless. Humans can use language to say the right things and that is not true. Only people who can use language to lie or deceive others.

15) Language has two subsystems namely the sound subsystem and meaning subsystems that enable language to have economic function. The economics diverse occurredby functional sound units that can be grouped and regrouped into meaningful units, e.g. phonemes into words.

16) The language can be used to talk about language itself.

\section{Language Functions}

Traditionally it is stated that language is a tool to interact or tools to communicate, in a sense, means to convey thoughts, ideas, concepts, or even a feeling. The concept that language is a tool to convey the thought has had a long history. However, in the sociolinguistic thought considered to be too narrow because the language activity is basically a "who speak what language to Whom, when, and to what end." Therefore, from the view of sociolinguistics, language functions can be viewed from different angles, such as speakers, listeners, topics, codes, and conversation purpose (Chaer and Agustina, 2004: 15).

From the point of speaker, language serves as a personal or private identity and Jakobson called it as emotive function. It means, speakers expressed their stand point on what they speak out. The speakers not only express emotions through language, but also showed emotion when delivering their speech. Therefore, the listener can understand whether the speakers in an angry, sad, or happy.

From the point of the listener and the speaker, the language has a function as a directive, which regulate the behavior of the listener, and Halliday defines as instrumental function, while Jakobson called rhetorical. From this angle, the language not only makes the listener to do something, but the activities were consistent with what the speaker wants. This can be done by the speakers through sentences that express a command, direction, demand, or seduction.

From the contact angle of the speaker and listener, the language has a fatigue function, Finnocchiaro called it as interpersonal and Halliday called it as interactional.

Despite Pranowo in Halliday (1996:63) also classify the function of language based on the concept beyond the language function as other experts do. They classify into seven functions as follows:

1) instrumental function is the function of the language used to manipulate the environment that led to a particular situation. 
2) regulatory function is the use of language that serves to control an event, such as approval, rejection, etc.

3) the representational function of language that serves to make a statement, present the facts, etc.

4) the use of interactional function of language serves to maintain the relationship in order to keep communications running smoothly, delivering jokes, master jargon, idioms used by the particular conversational partner.

5) heuristic function is the function of the language that is used to acquire knowledge in order to recognize the environment, such as a child wondering about what is seen.

6) personal function, namely the use of language that serves to express feelings, emotions, personality, etc.

7) The function of the imaginative use of language that serve to create a system or be imaginative ideas.

While Guy Cook in Pranowo (1989:94) developed a classification of language functions into two, namely the macro and micro functions. Macro functions are classified into seven as Halliday did, namely:

1) Emotive function, for example: the expression "mad", "great", "ouch", etc.

2) Directive function, for example: "Help me please", "Shoot him!".

3) Phatic function is when speaker going to start a conversation such as: "Can you hear me!".

4) Referential function of language is to convey information.

5) Metalinguistic function is the usage of language that focuses on the code itself.

6) Poetic function is the usage of language by selecting the form that contains the essence of the message, for example, one ad shows how powerful dairy companies exploiting the potential of the poetic function of language:

Chaedar : :Chaedar also want to go to school, Mom!"

Mother : : "Yeah, you will when you're growing, son!"

Chaedar : : "What can make me grow quickly Mom?"

Mother : "Drinking the best milk, son!"

7) Contextual function is the usage of language to create different types of communication, for example, "Good! Let's start this exercise !". While micro function is communicative forms of each category of macro functions.

\section{Language as a Communication Device}

After discussing language related to its nature and function, the language either realized or not it has an important meaning among their speakers. Language is a means of communication between members of the community in the form of symbols of sound produced by the speech organ. Language is also a tool of self-expression and served as a tool to show their identity as well. 
Through language, we can show our perspective, our understanding of the matter, the origin of the nation and our state, our education level, and even our character. Language becomes a mirror of us, both as a nation and as a self. In order for the communication goes well with both, the sender and receiver must have to master their own language.

According Gorys Keraf (1997:1), language is a means of communication between members of the community in the form of a symbol of sound produced by the speech organ. Perhaps there is an objection by saying that the language is not the only tool for communication. They argue that two persons or parties communicating by means of specific ways that have been agreed such as through paintings, smoke, sound of drum or casks and so on. But they should also recognize that when compared with the language, all communication devices before contains many weak aspects.

Basically, the language has certain functions that are used according to the needs of a person, i.e, as a tool for self-expression, as a means to communicate, as a tool to organize and adapt to social integration in the environment or circumstances, and as a tool for social control (Keraf, 1997:3).

Here are presented the role of language as a communication tool:

1) Language as a tool to interact with others. Condition for the communication occurred is need involvement of two or more persons conducting talk to each other. In this case interaction process is emphasized in order to allow interchange feedback between the speaker to his interlocutor, and vice versa.

2) Language reflects a person's level of education. An educated would be recalled better than uneducated people. The higher a person's education, the higher their speech wisdom. The emergence of this opinion because the interaction is often done by people who are well educated, influenced by the environment of residence, as well as the school environment or the working environment. So that educated people tend to interact with the environment that supports the use of language quality, than those who are less educated.

3) Indicates authority. A leader would have to be able to speak well rewarded subordinates. This is related to one's mastery of the language, if a leader can speak well, then he can express his ideas in a clear and straightforward so that shows the authority of the leader.

4) As the force of law. With language, a person can identify the language of selfdefense or rival. Someone who speaks, even to escape easily from the case addressed to him. This suggests that language can be implemented as an ability / skill in communicating.

5) Attract the customer. Language of good and interesting ads will make consumers interested in trying your product. In communications, advertising language is included in the scope of advertising. In an effort to convey the benefits and efficacy of the product, the process of communication can not be released from the distribution of a product to consumers. 
6) Indicates a person's social standing. With the language, one can reflect on his position in society. Diversity of languages mastered one will certainly differ from one to another, it is influenced by the language acquisition from the environment. So people who have a high diversity of languages, and be able to communicate well be seen as the privileged in society.

\section{E. The Relationship between the Communication, Language and Culture}

The link between communication and culture, could be seen from our daily practice of communication or interaction between individuals and groups. The language we use must have been influenced by where we live, as well as the ethnic neighborhoods around us.

In this case, culture in regard to human being way of life. Humans learn, think, feel, believe, and seek what is appropriate according to the culture. Language, friendship, custom, practice communication, social action, economic activity, politics, and technology, all these were based on cultural patterns. As for who speak Makassarese, Gorontalonese, Sundanese, Javanese, Malay, and English. This is all because they have been born or at least raised in a culture that contains these elements. What they do, how they act, a response to cultural functions. (Porter \& Samovar in Mulyana and Grace, 2006).

This means that communication and culture cannot be separated, because culture not only determines who is talking whom, about what, and where the communication takes place, but the culture also helped determine the encode messages, the meaning and the message he had for the conditions to send, pay attention, interpret the message. Actually, the whole repertoire of behavior we are very dependent on, the culture we grew up, in line with previously disclosed at the beginning of the discussion. Consequently, culture is the foundation of communication. If cultural diversity, it is also a variety of communication practices.

\section{F. The Essence of Culture}

There are various definitions of culture are very different, and it could be true, or it could be considered incomplete. This difference occurs because the compilers usually see the cultural definition in terms of different aspects.

Koentjaraningrat (1974: 217) explains that culture only humans possess, and grow along with the development of human society. For that Koentjaraningrat using something he calls "cultural framework", which has two aspects, namely the form of culture and cultural content. Referred to as a form of culture is either: (1) a form of ideas (cultural system), which is abstract, (2) behavior (social systems), which are rather concrete, and (3) a physical or objects, which are universal, meaning the seventh element in every society there are people in the world. The seven elements are: (1) language, (2) technology system, (3) livelihood systems, (4) social organization, (5) knowledge of the system, (6) religious system, (7) art. 
Kroeber and Kluckhorn in Pranowo (1952:86) has collected dozens of definitions of culture, and breaks it down into six categories according to the nature of the definition, namely: (1) a descriptive definition, the definition that emphasizes the elements of culture, (2) historical definition, the definition emphasizes that culture inherited social, (3) the definition of normative definitions emphasize the nature of culture as a rule of life and conduct. On the usefulness of culture in conformity with the environment, solving problems, and learn to live, (5) structural definition, the definition that emphasizes the nature of culture as a system patterned and orderly, (6) the genetic definition, the emphasis on the definition of culture as the work of man.

Based on the grouping of the above it can be seen that culture pervades all aspects and dimensions of human life. It can be said that any human activity with all the results and the result is included in the concept of culture.

Grouping cultural definitions made Nababan (1984) also showed that culture covers all aspects and elements of human life. Nababan cultural definition classifies into four categories, namely (1) the definition of a view of culture as a regulator and tie the community, (2) the definition of a view of culture as the things that man has acquired through learning or education (nurture), (3) the definition of a view the customs and culture of human behavior, and (4) the definition of a view of culture as a system of communication that people use to gain cooperation, unity, and survival of human society.

Based on the above in other words it can be said that culture is everything that concerns human life, including the rules or applicable law in society, the results of manmade, custom and tradition are wont to do, and as well as the interaction or communication tool used, the language and tools of communication is non-verbal.

\section{G. Language as a Cultural Reality discloser}

The existence of different theories about the relationship of language and culture. Some say that language is part of culture, but others say that language and culture are different, but have a very close relationship, so it cannot be separated. Some argue that the language is strongly influenced by culture, so that all things in the culture will be reflected in the language. Conversely, there is also a saying that the language and culture influence human thinking or public speakers.

One question of interest to linguistic experts is whether there is a relationship of language and thought the speakers with a different culture? With the variation of language is often associated with the presence of different cultures. In many ways the view was influenced by the work of anthropologists who tend to respond to the language as part of a culture that is defined as a socially acquired knowledge (Cahyono 1995: 409). The opinion asserts that language variation is closely related to the existence of different cultures.

Gee (1993: 7) states that human language is the result of a long evolution of man. Human language is different because human cultures are different, but the language and culture has a profound similarities because humans are basically the same. They have the same kind of eyes, kind of the same brain, the same biological basis. Human evolution has formed humans acquire and use specific language. 
To determine the relationship between language and culture significantly, we have to ignore the word level possessed a language. The question is whether culture affects language culturally significant than determining how much or what words will have a language?

Language is bound by cultural context. Put differently, the language can be seen as an extension of the culture. According to the Sapir-Whorf hypothesis, often called Linguistic Relativity Theory, in fact every language shows a typical symbolic world that depicts the reality of mind, inner experience, and the need for users to think, look at the environment, and the universe around it in different ways, and therefore behave differently.

The hypothesis put forward by Benjamin Lee Whorf and popularize and confirms the view teacher Edward Sapir states that (1) the language affects perception, and (2) the language affects thought patterns. Thus, the language was mastered ways of thinking and acting human. As an illustration, the fact that the Eskimos have about 20 words to describe snow, indicating that they are more sensitive in perceiving the reality of snow, because snow is an important factor in their lives. There are special words to describe snow was falling, wind-blown snow and form a line of soft snow on the ground, and so on. In this case, the categorization of the snow is so important to them because the snow could affect the lives and safety even for them. So also in classical Arabic, supposedly there is a word to describe 6000 camels, warnanta, body structure, gender, age, movement, condition, and equipment.

Sahara natives also have 200 words to describe dates, a staple in their lives, and 20 different ways to describe the dunes (Condon and Fathi Yousep in Dedi Mulyana, 2007:277). This signaled the importance of the objects in their culture. Meanwhile, in Zulu language, there are 39 words to express the color green. The number of names for the colors of the different green is showing concern for the Zulu people into nature and the places that they go through in the journey across the prairie, especially before they recognize automotive transport and national highways, (Lewis in Dedi Mulyana, 2007:277). Other than that, the word rice in English can be translated into three words in Indonesian different meaning, namely: gabah, beras, and nasi. It shows that we are more concerned with the people of Indonesia this thing than the English, so our main meals.

The use of tenses in English implies that the British people are very aware of the time and stressed the importance of time, as in the sentence:

a. They study English twice a week.

b. She studied English last night.

c. We are going to study English tomorrow.

d. Have you studied English today?

e. I have been studying English four years.

Levels of language in the Java language (kromoversus ngoko) and in the minds of Gorontalo show (read: social status) are different for those who use the language. For example: In the language of Gorontalo there are a numbers of word to the first person, the Wau and watiya, while for the second, is: Yio and tingoli. The word of "eating" can be translated into a number of words in Gorontalo language, such as:

- Monga, for self

- Miriziki and molamelo, for the people we respect

- Yukul, for a familiar peers or subordinates / maid

- Moluango, for animals

- Maam, for small children 
When we use the local language, the nature of the local language are layered it forces us to realize it or not to see each other in front of us with a particular category.

However, to some degree is the Sapir-Whorf hypothesis is true. Otherwise it is still talked about is the opposite of the Sapir-Whorf hypothesis says that culture affecting language. The fact also proves that the people whose activities are limited, as the tribes are isolated, have only vocabulary too limited. While the open society, the community members have an activity that is spacious, has a vocabulary very much. Compare, in Webster's English dictionary TM registered more than 600,000 words, while in the Big Indonesian Dictionary of no more than 60,000 words.

Thus, language is an important tool to unravel our social life. When the language used in the context of communication, it blends with its culture. It is believed that there is a natural connection between the language spoken by someone from a social group and a social identity. With his accent, vocabulary, or pattern-poka its discourse, a speaker identifies himself and is identified as a member of the group. Furthermore, through this membership, they illustrate the power and pride (Kramsch, 1998:66). Then, the words refer to a person experiences. Because they express facts, ideas, or knowledge of the world is going through. The words also reflect the behavior or beliefs of speakers, ideas, or anything else. In this case, the language can be said to express the reality of the culture.

However, members of social groups not only express the experience, they also create through language experience. They gave a name to that experience through tools they choose to communicate with others, for example; write a letter or send a message via e-mail, read the newspaper or interpret graphs. The manner in which a person's well spoken, written, or visual media produce meanings that can be understood by those who have it, such as through tone (tone) voice, accent, speaking style, body language or facial expressions. Through all aspects of verbal and non-verbal, the language adds cultural reality.

Indonesian people, and as some other eastern cultures have no direct in expressing what she feels. The meaning of the phrase "I love you" is a phrase that should not be found and used by the Indonesian people express their love. How it feels weird and rude in Indonesian culture. Indonesian people tend to express their love by showing sincerity and attention being deep and can be felt by the attention. If it turns teens Indonesia often and so easy to use the phrase "I love you" means that they have been uprooted from their cultural roots.

Thus, because of the close relationship between the language of this culture, there are experts who like their relationship as twins, the two things are inseparable. Or as a coin; side one is the language and the other is cultural (Chaer, 2003:71)

\section{H. Conclusion}

Language is a system of symbols used by humans to communicate or express ideas and thoughts to others. The language used is influenced or affected the culture and vice versa. Therefore it can be said that the language and culture has a very close relationship. Through the language of the person, his interlocutor can usually tell the background of the speaker. That's there is parable says that language indicate the nation.

\section{References}


Ahira, Anne. Peran Bahasa Indonesia dan Daerah Sebagai Komunikasi. (http://www.anneahira.com/bahasa-17353.htm).

Alwi, Hasan. 2004. Menabur Benih Menuai Kasih. Persembahan Karya Bahasa, Sosial dan Budaya untuk Anton M. Moeliono pada ulang tahunnya yang ke-75.

Cahyono, Bambang Yudi. 1995. Kristal-Kristal Ilmu Bahasa. Surabaya: Airlangga University Press.

Chaer, Abdul. 2003. Linguistik Umum. Jakarta: Rineka Cipta.

Chaer, Abdul dan Agustina, Leoni. 1995. Sosiolinguistik Perkenalan Awal. Jakarta: Rineka Cipta.

Gee, James P. An Introduction to Human Language: Fundamental Concepts in Linguistics. New Jersey: Prentice Hall. 1993.

Gorys, Keraf.1997. Komposisi. Ende-Flores: Nusa Indah

Koentjaraningrat. 1974. Pengantar Antropologi I. Jakarta: Rineka Cipta

Kroeber dan Kluckhohn. 1952. Culture, a critical Review of Concepts and Definitions. Chicago: Universit of Chicago Press.

Kramsch, Claire. 1998. Language and Culture. Oxford: Oxford University Press.

Kushartanti, Untung Yuwono dan Multamia RMT Lauder. 2005. Pesona Bahasa: Langkah Awal Memahami Lingustik. Jakarta: Gramedia.

Mulyana, Deddy. 2007. Ilmu Komunikasi; Suatu Pengantar. Bandung: PT. Remaja Rosdakarya.

Mulyana, Deddy dan Rahmat Jalaluddin. 2006. Komunikasi Antarbudaya. Panduan Berkomunikasi dengan Orang-Orang Berbeda Budaya. Bandung: PT. Remaja Rosdakarya.

Nababan. 1984. Pengantar Sosiolinguistik. Bandung:Angkasa.

Pranowo. 1996. Analisis Pengajaran Bahasa. Yogyakarta : Gajah Mada University Press.

Sahabuddin, Ahmad. 2011. Komunikasi Antarbudaya: Satu Perspektif Multidimensi. Jakarta: Bumi Aksara. 